\title{
The Role of Transformational and Transactional Leadership Approaches on Environmental and Ethical Aspects of CSR
}

\author{
Mustafa Changar * and Tarik Atan ${ }^{\text {D }}$ \\ Department of Business Administration, Faculty of Economic and Administrative Sciences, \\ Cyprus International University, Nicosia 99258, Cyprus; tatan@ciu.edu.tr \\ * Correspondence: 20167335@student.ciu.edu.tr
}

check for

updates

Citation: Changar, M.; Atan, T. The Role of Transformational and Transactional Leadership Approaches on Environmental and Ethical Aspects of CSR. Sustainability 2021, 13, 1411. https://doi.org/10.3390/ su13031411

Received: 30 December 2020

Accepted: 24 January 2021

Published: 29 January 2021

Publisher's Note: MDPI stays neutral with regard to jurisdictional claims in published maps and institutional affiliations.

Copyright: (c) 2021 by the authors. Licensee MDPI, Basel, Switzerland. This article is an open access article distributed under the terms and conditions of the Creative Commons Attribution (CC BY) license (https:// creativecommons.org/licenses/by/ $4.0 /)$.

\begin{abstract}
Corporations' accountabilities to implement socially responsible actions towards stakeholders are essential as organizations keep participating in competitive industries. Recently, applying leadership approaches has been the emphasis of both scholars and practitioners, but the concern has not been comprehensively examined. The purpose of this study is to investigate the influence of transformational and transactional leadership styles on environmental and ethical features of Corporate Social Responsibility (CSR), in financial services companies located in the United Kingdom (UK). The moderating factor of employees' years of employment in their respective companies is also examined. Offering contributions through an empirical appraisal of leadership and CSR is aimed. 384 employees working in the financial services companies in the UK were given a structured questionnaire to test our model. The employees offered viewpoints on the leaders, their selves, and the company. Suggested hypotheses were tested through Structured Equation Modelling (SEM). The study concluded that both transformational and transactional leadership approaches had positive impacts on the environmental and ethical aspects of CSR. Additionally, the moderating variable only had an impact on the relationship between transformational leadership and ethical CSR. The study proposes that complementary implementation of transformational and transactional leadership approaches can lead to enhanced socially responsible actions in organizations.
\end{abstract}

Keywords: transformational leadership; environmental corporate social responsibility; financial services sector

\section{Introduction}

In recent decades, Corporate Social Responsibility (CSR) has received the noteworthy attention of both academics and practitioners in business fields, especially on the features of environmental and ethical CSR [1,2]. Clarifying CSR is not a straightforward task; accordingly, it can be contingent upon perspective and point of view [3]. It can theoretically intersect with several other ideas, such as citizenship, sustainability, and ethics. CSR nurtures the prominence of meaning in work and life to equal status as well as ecological integrity and financial sustainability. It likewise helps to recognize what essentially companies are doing with their profits and how they are affecting society. The mounting emphasis on CSR is not to focus on shareholder standpoint by maximization of profit, but to highlight the stakeholders' perspective, including customers, government, suppliers, employees, and their prosperity [4]. In the sense of this exploration, the focus is on the employees' standpoint with regard to the environmental and ethical aspects of the business.

However, there is huge pressure for shareholder returns on the leaders of corporations, which can cause them to adopt a singular approach towards profit generation [5]. In addition, with the challenge of escalating globalization and intensifying competition leading to ethical conflicts, managerial leaders are challenged with the responsibility of setting ethical standards that oversee the behaviors of their employees within their organizations [6]. Huge business scandals of corporations such as Tyco international, Worldcon, 
and Enron, on the issue of profit and CSR, are some examples. Such conflicts might result in disregarding CSR if the proper leadership styles are not adopted. Companies' habits of conducting business are the reflection of what the leaders determine as acceptable or not acceptable behavior in that business. In return, such ways of directing business have the potential to massively affect society either positively or negatively.

A significant number of scholars proclaim that there is an optimal level of CSR, which will simultaneously maximize profit and satisfy the demand for CSR emanating from various stakeholder groups [7]. Leadership plays a vital role in order to determine the correct strategy for such optimal levels. According to Christensen et al. [8], the approach of leadership can strengthen CSR in the sense that it suggests process models and explanatory mechanisms to CSR. Therefore, organizations should place comprehensive attention on selecting virtuous leaders, who will influence their employees positively into engaging in environmentally and ethically responsible actions. Targeting to advance in certain areas with an incompetent or inconsiderate leader towards CSR would be a mistaken starting point for further goals of development. The theories of transactional and transformational leadership have been previously called for research, since they deliberate a broader display of leadership components, as drivers of CSR practices. Transformational leadership has become the leading topic of interest among academics since it provides a significant and positive impact on the performance of organizations as well as the employees [9].

Academics have likewise emphasized the link between leadership styles and CSR [10-12], where various studies focused on transformational and transactional leadership [13,14]. Even though the dominating literature states a visible link between leadership and CSR, scholars' findings on the specific styles of leadership inclined to be differing at times. Precisely, Ali et al. [14] concluded that transformational leadership has a positive relationship with CSR in relation to media, employee, customer, and non-profit organizations. Whereas, according to Ho et al. [15], transactional leadership enhances a corporation's CSR practices while transformational leadership does not. Moreover, a substantial part of the literature explored either leadership or CSR as mediating factors while researching other outcomes such as organizational or job performance. For instance, Manzoor et al. [16] concluded that CSR considerably mediates the relationship between transformational leadership and job performance.

Nonetheless, this research takes a more profound direction through numerous distinctive ways. Firstly, the focus is solely on environmental and ethical CSR which are two chief components of social responsibility, through keeping the employees' perspective as the center of attention. There has been research on the direct link between leadership styles and environmental CSR [17]. However, the differences are still existent with the addition of ethical CSR, location of the research, and unrelated moderating variables. In addition, employees' years of employment in their current company is considered as a crucial factor, since it is directly connected with the time spent under their companies' norms. It has been suggested that increases in length of employment are associated with more favorable supervisor ratings [18], since they can lead to an enhanced understanding between the leaders and the employees. Thus, it is added as a moderating factor between leadership styles and CSR.

Even though previous research has been conducted in different countries and industries $[19,20]$, not many have been carried out within the United Kingdom (UK) framework, especially in the financial services sector, which is an industry where an excessive singular approach towards profit generation is anticipated. The United Kingdom has a stable economy, with a growth rate between $1.3-2.3 \%$ in each of the past five years [21]. Several vital details assist to comprehend the importance of the financial services sector in the UK. The financial services sector accounted for 7\% of the UK's economy in 2018 with a contribution of GBP 132 billion, which is the seventh-largest share within the Organization for Economic Cooperation and Development (OECD) countries [22]. In addition, the UK's banking sector assets (USD 10.8TRN) are the largest in Europe and its global net exports of financial services (USD 88BN) are the largest in the world [23]. 
Within the context of this research, the financial services sector in the UK is deliberated to be central to explore the CSR concept, since this sector has been faced with complications such as low disclosure levels of CSR reports of businesses operating in the financial services sector of the UK, as well as negative social impact due to periodically massive restructuring and redundancies in employment, where the UK based workforces of banks like Citigroup and Royal Bank of Scotland were made redundant [24]. However, Day and Woodward [25] highlighted that such low disclosure is related to size, as the likelihood of compliance rises with bigger companies, which might indicate a resource issue. On the contrary, there are substantial actions towards CSR as well, with the application of the green finance concept, where the funding of investors is directed towards making improvement on acknowledged environmental goals, as 26 investment companies and unit trusts play an active role in this process, including giant corporations such as Parvest and Allianz [26].

Inclusion of the leadership styles is believed to be imperative to this research, after perceiving such increasing action towards CSR in the financial services industry. However, the previous research in the UK financial services sector has linked leadership styles with organizational performance and organizational culture [27], or used differing leadership styles with regard to CSR, such as visionary and servant leadership [28]. Consequently, in the financial services sector of UK, there is a lack of research carried out to examine the effect of transactional and transformational leadership styles on environmental and ethical CSR, with the moderating effect of employees' years of employment in their respective company. In consequence, this research intends to fill the gap. This research can present outcomes that will potentially present clear pathways to the leaders of the financial services companies to consider specific styles of leadership that can result in socially responsible actions, which benefits the whole society. Moreover, the findings can be the starting point of more profound research in the area of leadership and CSR in the financial services sector.

The remaining parts of this article are prepared in the following manner. The subsequent section provides the literature review, which leads to hypotheses development. After Section 2, Section 3 delivers the clarification of the methodology in detail, which includes the data collection method and procedure, sample, as well as the method of data analysis. Section 4 explains the data with its analysis and findings, and then the study is settled with discussion and conclusion presented in Section 5.

\section{Literature Review and Hypotheses Development}

\subsection{Literature Review}

\subsubsection{Corporate Social Responsibility}

CSR-related research has been previously applied to public relations, business ethics, corporate sustainability, and leadership. One of the ways to define CSR is a company's commitment to managing the environmental, economic, and social influences of its actions sensibly and in line with public expectations [29]. However, CSR is a very broad concept that can take various forms according to the company and its operating industry [30]. For instance, certain businesses adopt philanthropic actions through donating money or services, as well as in the form of non-profit organizations. On the other hand, others could focus on the environmental aspect of CSR by engaging in the production of environmentally friendly goods. However, the approaches are similar in the sense that they aim to manage their processes with the aim of impacting society positively.

The concept of social responsibility was noticeable even centuries ago. Nevertheless, the first work of the literature with regard to businesses socially responsible practices, as well as addressing what those responsibilities are, was noticed in the 1950s, where Bowen [31] clarified CSR as "the obligations of business to pursue those policies, to make those decisions or to follow those lines of action which are desirable in terms of the objectives and values of our society". CSR started to be widely used in the 1970s. Globalization was one of the crucial elements in the extensive use of CSR since the development of many multinational companies increased the need for transparency as well as social responsibility [32]. Moreover, two publications made by the Committee for Economic Development 
(CED) during the 1970s acknowledged that businesses' basic purpose is to constructively serve the needs of the society, which established the social expectations of the public with regard to CSR [33]. In the 1980s, Jones [34] proposed the interesting perspective of CSR under two facets. The first one was the voluntary actions unaffected by the compulsory forces of law, whereas the second facet was a broad obligation that goes beyond the stakeholders.

Moving on to the 1990s, certain themes of CSR continued developing such as corporate citizenship, stakeholder theory, business ethics, and sustainability. Global events like the creation of the European Environment Agency (1990) and the implementation of the Kyoto Protocol (1997) had major roles in the development of CSR in this era. During the 21st century, the CSR concept was evolved further with the addition of new terminologies as well as establishing firm connections with other concepts. One of the keystones was Smith's [35] explanation that companies need to implement CSR into their strategic perspectives with the aim of fulfilling their long-term obligations towards society. Subsequently, this approach was popularly used as strategic CSR in different contexts. Moreover, a different perspective on CSR was the new strategic business that includes the commitment of corporations with the backing of the systematic allocation of resources for conveying respect and promotion to individual rights, society growth, and environmental care [36]. Due to the massive global impact of the Covid-19 pandemic in current times, CSR practices of businesses are likewise challenged in the UK. However, He and Harris [37] debate whether corporations can assess the current situation as an opportunity to address urgent environmental matters through adopting more genuine and reliable CSR practices. As an example, the European Union (EU) has demonstrated observable levels of adaptability during such crises, through increasing its attention on climate change [38].

Ethical CSR is a more broad-spectrum in the sense that ethics are a fundamental part of all the previously mentioned aspects of CSR, but environmental corporate social responsibility (ECSR) has become a distinctively crucial topic in recent times, after the substantial increase in environmental issues occurring as a result of businesses inconsiderate actions. ECSR can be defined as a concept on companies' extra effort of incorporating environmental concerns in their business operations and their interaction with their stakeholders [39]. It is viewed as the contribution that firms make to sustainable development by balancing and improving environmental impacts without damaging economic performance. At an international level, the International Chamber of Commerce has sanctioned a Business Charter for Sustainable Development which contains numerous principles that should be obliged by private companies with the aim of achieving sustainable growth. Flammer [40] concluded that ECSR improves stakeholders' relationships and reactions with each other as well as attracting a higher number of customers. Other CSR actions also have led to rewarding contributions towards the environment, including forest conservation, water cleansing drives, afforestation, and environmental awareness [41]. Research has likewise discovered that corporations that are eco-friendly and demonstrate good CSR practices enjoy increased consumer purchase preference [42].

In addition, the study of Abdul and Ibrahim [43] conducted in Malaysia suggests that whether an organization is displaying CSR actions can depend on the characteristics and style of the leaders in the company. Agle et al. [44] have similarly found strong support on the relationship between the values of CEO's and corporate social performance, which highlights the importance of leadership on CSR.

\subsubsection{Leadership}

Leadership is a major subject that is widely researched and discussed, where research dates back to Galton's study of Hereditary Genius [45], advocating that leaders' qualities are genetic and transported from generation to generation. Batten [46] defined leadership as "the development of a clear and complete system of expectations in order to identify evoke and use the strengths of all resources in the organization the most important of which is people". Northouse [47] enlisted numerous components central to the phenomenon of leadership such as: leadership being a process, leadership containing influencing others, 
and goals being shared by leaders and their followers. The differences in definitions of leadership by scholars are present in how leaders motivate, and who has a say in the aims of the organization [48]. In recent times, the main focus of the leaders is shifting from "forcing" followers to "persuasion", then "influencing", and lastly followed by leaders and followers influencing each other. Hofstede [49] deliberated the relationships among leadership, subordination, and culture, where the finding was presented that leadership and subordination are inseparable, and ideas about leadership reflect the dominant culture of a country. Bennis and Nanus [50], after exploring the subject for a considerable amount of time, stated that "never have so many labored so long to say so little" and "leadership is the most studied and least understood topic of any in the social sciences".

It is viewed as essential to examine the history of leadership theories to appreciate how transactional and transformational theories emerged. At the outset, trait theories tended to focus on personality, physical, social, or intellectual traits in order to distinguish leaders from non-leaders [51]. Some examples of leadership traits are extroversion, openness, and conscientiousness [52]. Findings of a meta-analysis showed that the Big Five personality dimensions were substantial predictors of leader effectiveness and leadership emergence, which supports certain claims of trait theories of leadership [53]. Myung and Choi [54] demonstrated that leaders' "dark triad" trait, which is a psychological term explaining negative dispositions, undesirably affects the perception of CSR. On the other hand, trait theories were criticized for the suggestion that traits do not change in different situations so people are the same at all times.

Looking beyond the trait paradigm, studies on leadership focused on how behaviors predicted leader effectiveness inside the organizations, inclusive of the CSR aspect. Behavioral theories of leadership suggest that specific behaviors differentiate leaders from non-leaders, so identifying and teaching them to potential leaders is possible. The biggest difference in behavioral theories compared with trait theories is the suggestion that leadership is not predetermined and can be taught. Behavioral theories narrowed the explanation of leader behavior to two dimensions: initiating structure and consideration [55]. Blake and Mouton's [56] Managerial Grid theory focused on different types of behaviors to assess leadership styles, such as concern for people, and concern for production. Moreover, Mcgregor [57] conveyed Theory X and Theory $Y$, proposing two aspects of human behavior at work. The theory promoted participative decision-making and team development by assisting individual requirements and aligning individual and group purposes. However, it was challenging to state which style of leadership was important in enabling one group to function better than the other. Therefore, it is almost impossible to determine one leadership style which would be accurate for all leaders under all circumstances.

Accordingly, the next phase of leadership theories focused on contingency theories, which dealt with the missing link of the environment in which the leader exists. Contingency theories do not completely disregard the leaders' personality and behavior but did not consider them as the most important dynamics for defining the success of the leader. According to Fiedler's [58] contingency model, a leader is effective when his or her style of leadership fits with the requirements of the situation. Moreover, the path-goal theory of House and Mitchell [59] was a process in which leaders chose particular behaviors that are best fitted to the employees' requirements and the working environment, so that they may best guide the workers through their path in the obtainment of their daily work activities. However, one criticism aroused when assessing Fiedler's model, which was contingency variables being complex and difficult to determine [60].

Moving onto the contemporary approaches of leadership, it can be seen that they are primarily focused on the personal influence of the leader to develop and inspire followers in order to achieve organizational goals and make a difference in the community. Some examples include charismatic leadership, transactional leadership, transformational leadership, and servant leadership. House [61] argued that charismatic leadership is rooted in behavioral and personal characteristics of the leaders, and such qualities can inspire followers through the appropriate articulation of the organizational vision. Besides that, 
servant leadership comprises the leader displaying the features of empathy, listening, stewardship, and commitment to personal growth toward others [62].

As contemporary approaches which stand out, transformational and transactional leadership theories were initially introduced to the literature as a concept by Burns [63]. Subsequently, Bass [64] developed the theory and stated that transactional and transformational leadership are independent but complementary ideas. The style of transactional leadership is where leaders motivate followers in the direction of established goals through a reward and punishment system [65]. In exchange for receiving the required work satisfactorily within the agreed time limits, the leader awards the followers with rewards for their performance. Major components of transactional leadership are the contingent reward, management by exception, and laissez-faire [66]. To begin with, the contingent reward component is related to the contribution of rewards in terms of extra pay or bonuses. Such leadership behavior is concentrated on describing effort-reward relationships and contains interactions that take place between a leader and the followers. Management by exception can occur either passively, where the leader intervenes only when the standards are not met, or actively when the leader is involved during the whole process taking corrective actions. Even though a corrective approach may be observed as negative, an active approach tends to be effective in certain circumstances. Lastly, laissez-faire leaders give the employees complete autonomy, and they completely avoid getting involved regarding how they do their work [67].

Transformational leadership can be defined as inspiring employees to transcend their self-interests for the benefit of the organization, which can also have an extraordinary effect on followers. These leaders create an appearance of convincing and encouraging vision for the future [68]. On the other hand, Yukl [69] stated that similar to most leadership theories, transformational leadership theory adopts a heroic leadership stereotype, where effective performance by an organization, group, or individual is assumed to be contingent solely on leadership by an individual with the abilities to find the accurate path and motivate others to take it. Four chief features are idealized: influence, inspirational motivation, intellectual stimulation, and individualized consideration. Idealized influence is concerned with providing vision and a sense of purpose, which creates admiration, belief, and confidence from followers [70]. Inspirational motivation is about being able to encourage followers to have the same passion and motivation to fulfill organizational goals. The inspirational motivation and idealized influence dimensions are vastly correlated and are occasionally combined to form a measure of charisma [71]. Displaying the intellectual stimulation character instigates employees to discover new ways of doing things, as well as generating new opportunities to learn. Last of all, individualized consideration is regarded as giving personal attention to followers, and making individuals feel exclusively valued.

\subsection{Hypotheses Development}

Previous research on leadership largely agreed that although there are many aspects to leadership, they commonly have important effects on corporate social responsibility. Some of these leadership attributes are authenticity [72], morality [73], as well as rolemodelling [74]. Furthermore, particular leadership approaches such as ethical leadership have both direct and indirect effects on CSR, through encouraging adhocracy values in organizations [75]. According to Waldman et al. [7], research that ignores the role of leadership in CSR may perhaps yield imprecise deductions with regard to the antecedents and consequences of CSR activities. Eventually, implementing efficient leadership strategies has crucial effects on the CSR actions of employees as well as the operating system of corporations. Centered on the above argument, the hypotheses for this article were generated.

Referring to Juneja [76], transactional leaders are established to be moderately effective in managing efficiency decisions that are intended at improving productivity and lowering costs. Moreover, they are highly instruction and action-oriented, and their association with the followers tends to be transitory as well as not being based on emotional bonds. According to Jacobs et al. [77], transactional and transformational leadership styles can 
work in conjunction with each other and express value to each other through interaction. Both types of leadership styles might be required in the same business in order to equalize each other and assist to achieve the growth and development of objectives. Transactional leaders ensure the team is running smoothly and producing results in the present day, whereas transformational leaders put emphasis on innovation and seek future advances.

Preceding research provided unsettled outcomes, especially with regard to the relationship of transactional leaders with different aspects of CSR. For instance, even though Kanungo [78] led a research on the ethical values of leaders, and concluded that transactional leadership behavior is ethical based on certain sets of values that are teleological with mutual philanthropic motives; the same study exhibited that other leadership styles like charismatic leadership are rooted in stronger ethical values. In addition, the statements were proposed that there is a relationship between transactional leadership and CSR practices, although it is not as strong as transformational leadership with regard to ethical and environmental aspects, respectively $[79,80]$. Furthermore, Tuan [81] has found that transactional leaders are prone to CSR activities merely when the organizations primary stakeholder is emphasized, which includes only certain aspects of CSR such as legal and economic. Eventually, the correct application of transactional leadership with proper incentives can potentially lead to higher successful CSR practices [82]. In line with the argument above, the following two hypotheses were proposed:

Hypothesis 1 (H1). Transactional Leadership will positively influence Ethical CSR.

Hypothesis 2 (H2). Transactional Leadership will positively influence Environmental CSR.

The theory of transformational leadership differentiates itself from the preceding contemporary theories, based on its alliance to a greater good, since it involves the participation of the followers in activities that will lead to a certain superior social dividend. Leaders displaying transformational actions receive high respect, trust, and loyalty from their subordinates and, in return, they make an additional effort to ensure that leaders understand their employees' requests and feelings [83]. Bass and Avolio [84] state that the style of transformational leadership crosses hierarchical echelons so it is transparent on the bottom floor as well as at the top of the hierarchical chain. Waldman et al. [85], advocates that CEOs displaying transactional leadership characteristics significantly improve the performance of their organizations. Transformational leaders are also identified as exhibiting more citizenship behaviors such as sportsmanship, altruism, and courtesy, as well as aiming to instill the same values in their subordinates [86]. The full range of leadership, as measured by the Multifactor Leadership Questionnaire (MLQ), indicates that all leaders display a frequency of both the transformational and transactional features, but each leader's profile includes more of one and less of the other. The leaders who are more satisfying to their subordinates and who are more influential as leaders tend to be more transformational and less transactional.

The findings of transformational leadership dominate the literature with more consistent results. Referring to the study undertaken by Robertson and Barling [17], environmentallyspecific transformational leadership has an important role in the greening of organizations, through positively influencing employees' pro-environmental passion and behaviors. Turner et al. [87], with regard to the ethical aspects, concluded that transformational leaders were perceived by their subordinates with having higher moral reasoning. Moreover, transformational leaders likewise motivate managers into a better understanding and commitment to CSR activities [88]. This study combined theoretical and empirical research and interviewed managers of six different organizations in Australia, and it recommended testing similar approaches in different industries and countries. Besides that, Hadi and Rasool [89] revealed that transformational leadership increases the autonomous motivation of employees, which acts as a catalyst for pro-environmental behaviors at their respective workplaces. Moreover, perceived CSR is found to mediate the relationship between transformational leadership and affective organizational commitment, as well as trans- 
formational leaders increasing social responsibility through the perception of staff [90]. Even though this research will look for direct links between transformational leadership and environmental and ethical CSR, grounded on prior arguments, the subsequent two hypotheses were suggested:

Hypothesis 3 (H3). Transformational Leadership will positively influence Ethical CSR.

Hypothesis 4 (H4). Transformational Leadership will positively influence Environmental CSR.

Stakeholder theory suggests that the demographic composition of leaders leads to different strategic choices, including the area of CSR [91]. As an example, Spanish women were established to be more adaptable and effective in comparison to Spanish men while implementing CSR practices, through applying the transformational leadership approach [92]. Tenure, which can be referred to as years of employment in the current company, is likewise part of this demographic composition. Employees' length of time at their respective companies increases their association with leaders, thus, they become more influenced from their leaders.. With amassing tenure in organizations, employees tend to become progressively acquainted with their role as well as the corporate norms, objectives, and organizational culture [93]. Huang [94] observed 392 firms from a sample of 661 to explore the relationship between CEO characteristics and consistency in CSR, declaring that CEO length of employment positively affects CSR performance. The study of Steffens et al. [95], on organizational tenure in the financial industry, found that employee tenure is positively correlated with organizational performance, in association with other factors such as team and leader tenure. The common observation from such studies is the occurrence of years of employment in the company affect employee behavior, organizational commitment, and taking charge [96-98], which can potentially create the circumstance of moderating the relationship between leadership styles and CSR. Because of these arguments, the following hypotheses were proposed:

Hypothesis 5 (H5). Employees' years of employment in the current company will positively moderate the relationship between Transformational Leadership and Environmental CSR.

Hypothesis 6 (H6). Employees' years of employment in the current company will positively moderate the relationship between Transformational Leadership and Ethical CSR.

Hypothesis 7 (H7). Employees' years of employment in the current company will positively moderate the relationship between Transactional Leadership and Environmental CSR.

Hypothesis $\mathbf{8}$ (H8). Employees' years of employment in the current company will positively moderate the relationship between Transactional Leadership and Ethical CSR.

\section{Methodology}

The financial services sector is becoming more apprehensive with CSR, due to an increasing concern towards CSR throughout the whole world, which inspires leaders to make wiser decisions on this aspect. Because of that, the introduction of concepts such as "green finance" are gaining extensive attention from investors. Leaders can create desirable CSR actions in the corporations by influencing their subordinates. When the employees individually feel that CSR is an important factor of their work, the process of changing the organizational actions would be simplified towards ethical and environmentally responsible actions. It is critical for financial services firms to avoid adopting a singular approach towards profit generation. In light of these considerations, the objective of this study is to examine the effects of leadership styles on Corporate Social Responsibility, with the moderating effect of years of employment of employees, on financial services companies located in the UK. Precisely, the goal is to investigate the effects of transformational leadership and transactional leadership on environmental CSR and ethical CSR. In the current research, 
the model presented in the following Figure 1 demonstrates the links between leadership approaches, CSR aspects and the moderating variable.

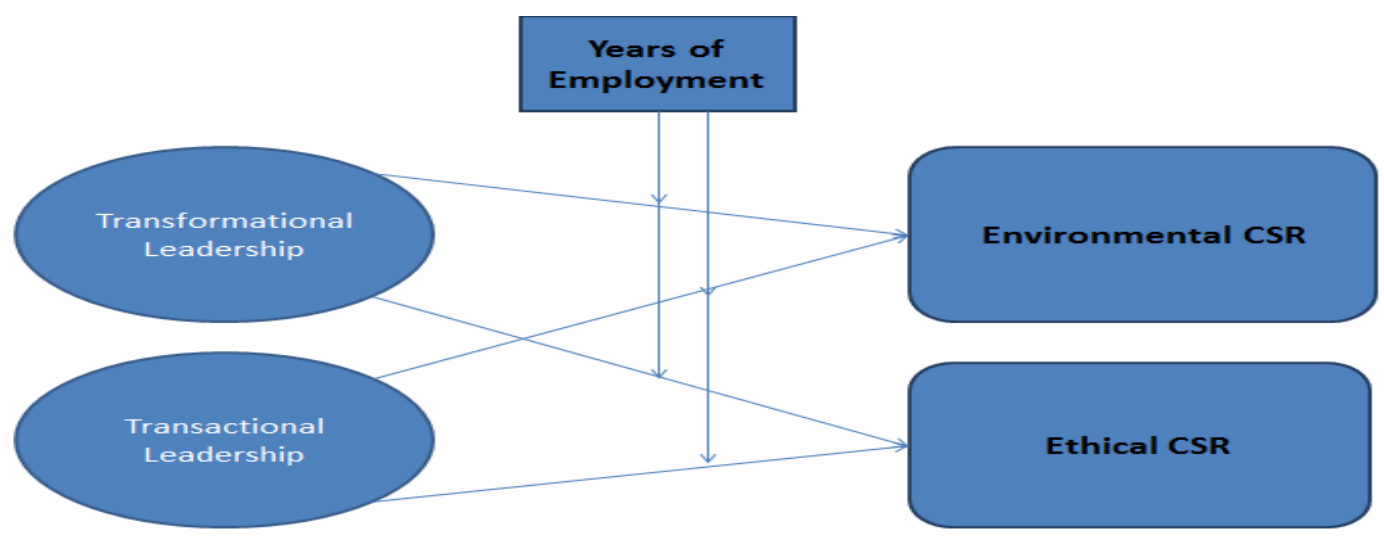

Figure 1. The research model.

\section{Methods of Data Collection and Analysis}

Measuring the "Transformational Leadership" (TF), "Transactional Leadership" (TSC), "Environmental Corporate Social Responsibility" (ECSR), and "Ethical Corporate Social Responsibility" (Ethical CSR) items were shaped through preceding studies $[17,99,100]$. For the items of transformational and transactional leadership, as have others [17,101,102], we used selected items from the Multifactor Leadership Questionnaire [99] in an attempt to escalate the quantity of responses by keeping the survey precise. TF, TSC, ECSR, and Ethical CSR were measured with 10,6, 7, and 5 items, respectively, as well as 1 item to determine the moderating variable of employees' years of employment in their current company, out of which 1 item from the TSC measure was established to have a loading value below the threshold and was consequently deleted from rest of the examination (see Appendix A). Participators were asked to provide their perspectives regarding numerous assertions in relation to the independent and dependent variables of the research, to be precise: "Transformational Leadership", "Transactional Leadership", "Environmental Corporate Social Responsibility", and "Ethical Corporate Social Responsibility". Measurement of the statements was grounded on a 5-point Likert scale extending from 1 (strongly disagree) to 5 (strongly agree).

Personnel who were employed in financial services organizations in the UK were the targeted population of this research. The list of financial services companies in the UK was taken from Aurigin [103], which is a global deal origination platform that contains such lists for investment opportunities and other purposes. The companies from the financial services industry were selected randomly due to time and resource constraints. Official data from the UK Parliament [22] shows that there are 1.1 million employees working in financial services, who were chosen by way of opportunity sampling. Consequently, the "Survey System" sample size calculator was the technique of outlining the absolute sample size, making an allowance for a 5\% margin of error, as well as a $95 \%$ confidence level. The size of the sample was measured as 384 . One representative employee was contacted from each firm, and they were requested to allocate the questionnaire to the co-workers, to quicken the distribution process. The employees did not have any managerial roles within their respective companies. Necessary background information regarding the research was presented at the outset of all questionnaire forms. The targeted sample size of 384 was reached on the 413th questionnaire directed to the employees. Regarding the demographic characteristics of the sample, the data showed that 225 participants were male (58.9\%), and 157 participants were female (41.1\%). Moreover, the age distribution of participants is perceived to be largely between 25 and 34 years old (50.3\%). The remaining percentage is shared between 18 and 24 years old (27.7\%), 35 and 44 years old $(13.9 \%), 45$ and 54 years 
old (5.8\%), and above 55 years old (2.4\%). The educational background of the sample size is mainly with an undergraduate degree $(65.2 \%)$, where the others had a postgraduate degree (22\%), high school diploma (9.9\%), and Ph.D. (2.9\%). Additionally, the descriptive statistics and correlations between the main variables are presented in Table 1.

Table 1. Descriptive statistics and correlation matrix.

\begin{tabular}{|c|c|c|c|c|c|c|}
\hline Construct & Mean & $\begin{array}{c}\text { Std. } \\
\text { Deviation }\end{array}$ & (1) & (2) & (3) & (4) \\
\hline Transformational Leadership (1) & 3.57 & 0.66 & 1 & 0.764 & 0.187 & 0.552 \\
\hline Transactional Leadership (2) & 3.70 & 0.71 & & 1 & 0.134 & 0.549 \\
\hline $\begin{array}{c}\text { Environmental Corporate Social } \\
\text { Responsibility (3) }\end{array}$ & 3.78 & 0.69 & & & 1 & 0.253 \\
\hline $\begin{array}{l}\text { Ethical Corporate Social } \\
\text { Responsibility (4) }\end{array}$ & 3.96 & 0.64 & & & & 1 \\
\hline
\end{tabular}

The Structural Equation Modeling (SEM) technique was used to analyze data, in order to perceive whether the hypothesized model was applicable. The method of Confirmatory Factor Analysis (CFA) was conducted with the aim of measuring the validity and reliability of the model. Subsequently, the full structural model was assessed to test our hypotheses. Table 1 exhibits the descriptive statistics of the main variables.

\section{Data Results and Analysis}

The data were analyzed by using the Statistical Package for Social Sciences (SPSS) for Windows 25.0 and Analysis of Moment Structures (AMOS) 23.0 programs. Reliability assessment was conducted in order to test the dependability of the questionnaire, as well as applying Confirmatory Factor Analysis through AMOS to test the validity. After that, Structural Equation Modelling (SEM) was applied to perceive the accountability of the hypotheses. SEM was perceived to be an ideal approach for further analysis, as it enables testing of a set of hypotheses simultaneously while accounting for measurement error $[104,105]$.

In addition, it was also tested whether the data were normally distributed, which can be investigated through a Quantile-Quantile Plot drawing [106]. The normal distribution of the data is dependent upon the skewness and kurtosis values being around \pm 3 [107]. The outlier values increase the error variance of values and, thus, they affect the power of statistical tests. It was checked whether there were outlier values in the data set for such a reason. Since the applied questionnaire was found to be normally distributed, parametric tests were chosen to be applied for statistical assessments. A T-Test was used to compare two independent groups of quantitative data, and Analysis of Variance (ANOVA) was applied to test more than two groups.

The correlation analysis shown in Table 1 was used in order to test the relationship between the variables. As a result, it was comprehended that Transformational Leadership positively correlates with Transactional Leadership $(\mathrm{r}=0.764, p<0.05)$, Environmental CSR $(\mathrm{r}=0.187, p<0.05)$, and Ethical CSR $(\mathrm{r}=0.552, p<0.05)$. Likewise, Transactional Leadership positively correlated with Environmental CSR $(r=0.134, p<0.05)$ and Ethical CSR $(r=0.549$, $p<0.05)$. There was a positively correlated relationship between Environmental CSR and Ethical CSR as well $(\mathrm{r}=0.253, p<0.05)$.

Besides, the following Figure 2 presents the relationship between the independent variables and the dependent variables, which will be analyzed in detail on the subsequent parts of this section. 


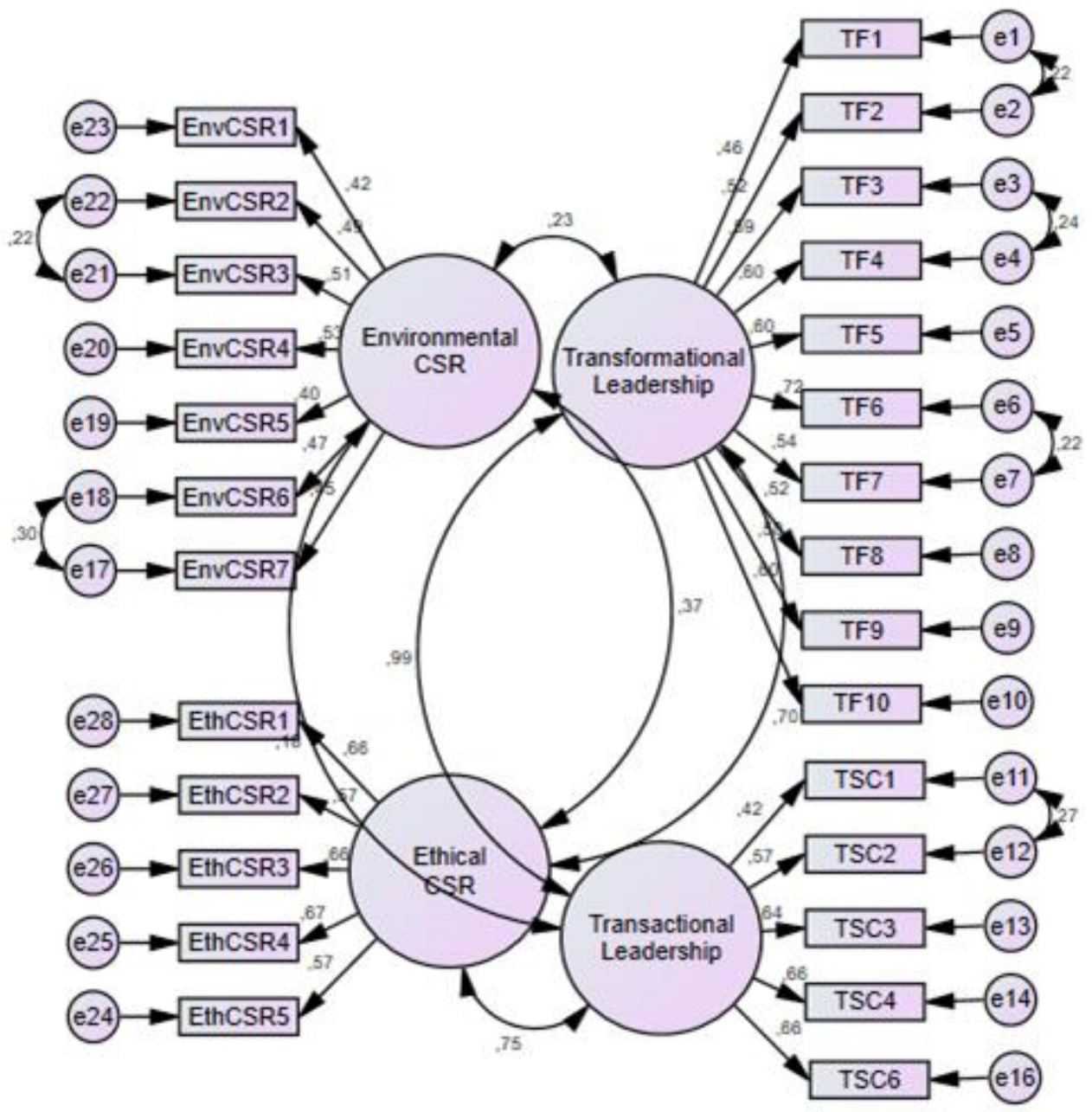

Figure 2. First Order many factored Confirmatory Factor Analysis.

The measurement model's reliability was established by utilizing Cronbach's Alpha. The values at the level of 0.60 and above regarding Cronbach Alpha indicate that the measurement is reliable and has high convergent validity [108]. The Cronbach's Alpha calculations showed 0.836 for Transformational Leadership, 0.738 for Transactional Leadership, 0.679 for Environmental CSR, and 0.761 for Ethical CSR, which are all reliable outcomes. In addition, entire correlations between the variables exhibited item factor weights above 0.40 , which indicates valid relationships between the variables. These results can be observed in detail from the following Table 2 .

Moving to the next measure, the Confirmatory Factor Analysis shows that the Structural Equation Modelling results of the model are meaningful at the level of $p=0.000$. The analysis led to the exclusion of one item (TSC5) from the measurement due to the low factor level. The remaining factors were found to be correlated with the model. While improving the model, the variables that lower the fit were determined, and new covariance was formed for high covariance values on residual values. The newly formed index calculations are shown in the following Table 3 where the optimal value levels are reached. 
Table 2. Reliability Assessment.

\begin{tabular}{cccc}
\hline Variable Name & Cronbach's Alpha & Item & Weights \\
\hline Transformational Leadership & 0.836 & TF1 & 0.462 \\
& & TF2 & 0.520 \\
& & TF3 & 0.588 \\
& & TF4 & 0.604 \\
& & TF5 & 0.596 \\
Transactional Leadership & TF6 & 0.719 \\
& & TF7 & 0.538 \\
& & TF8 & 0.519 \\
& & TF9 & 0.576 \\
& & TF10 & 0.605 \\
\hline Environmental CSR & & TSC1 & 0.423 \\
& & TSC2 & 0.569 \\
& & TSC3 & 0.628 \\
& & TSC4 & 0.660 \\
& & TSC6 & 0.661 \\
\hline \multirow{2}{*}{0.679} & EnvCSR1 & 0.419 \\
& & EnvCSR2 & 0.489 \\
& & EnvCSR3 & 0.509
\end{tabular}

Table 3. Structural Equation Modelling Goodness of Fit Index.

\begin{tabular}{ccc}
\hline Construct Item & $\begin{array}{c}\text { Structural Equation } \\
\text { Modelling Values }\end{array}$ & Optimal Values \\
\hline$\chi^{2} / \mathrm{df}$ & 1.626 & $\leq 3$ \\
Root Mean Square & 0.041 & $\leq 0.08$ \\
Error of Approximation & 0.909 & $\geq 0.80$ \\
Goodness of Fit Index & 0.890 & $\geq 0.80$ \\
Adjusted Goodness of Fit Index & 0.930 & $\geq 0.80$ \\
Comparative Fit Index & 0.838 & $\leq 0.80$ \\
Normed Fit Index & 0.049 & \\
Standardized Root Mean & & \\
Square Residual & &
\end{tabular}

The following part of this section will examine the relationship between the variables in detail. To begin with, the relationship between the independent variable of Transformational Leadership and the dependent variable of Environmental CSR was studied, with the addition of employees' years of employment in their current company, which was the moderating variable. The appraisals revealed that Transformational Leadership has a positive and statistically meaningful effect on Environmental CSR $(p<0.05)$, where 1 unit of increase in Transformational Leadership leads to 0.255 units of increase in Environmental CSR $(\beta=0.255)$. This relationship is an acceptable level of fit between the variables. On the other hand, the results showed that the moderating variable of years of employment 
has no moderating effect on the relationship between Transformational Leadership and Environmental CSR $(p>0.05)$. These results are shown in the following Figure 3 and Table 4.

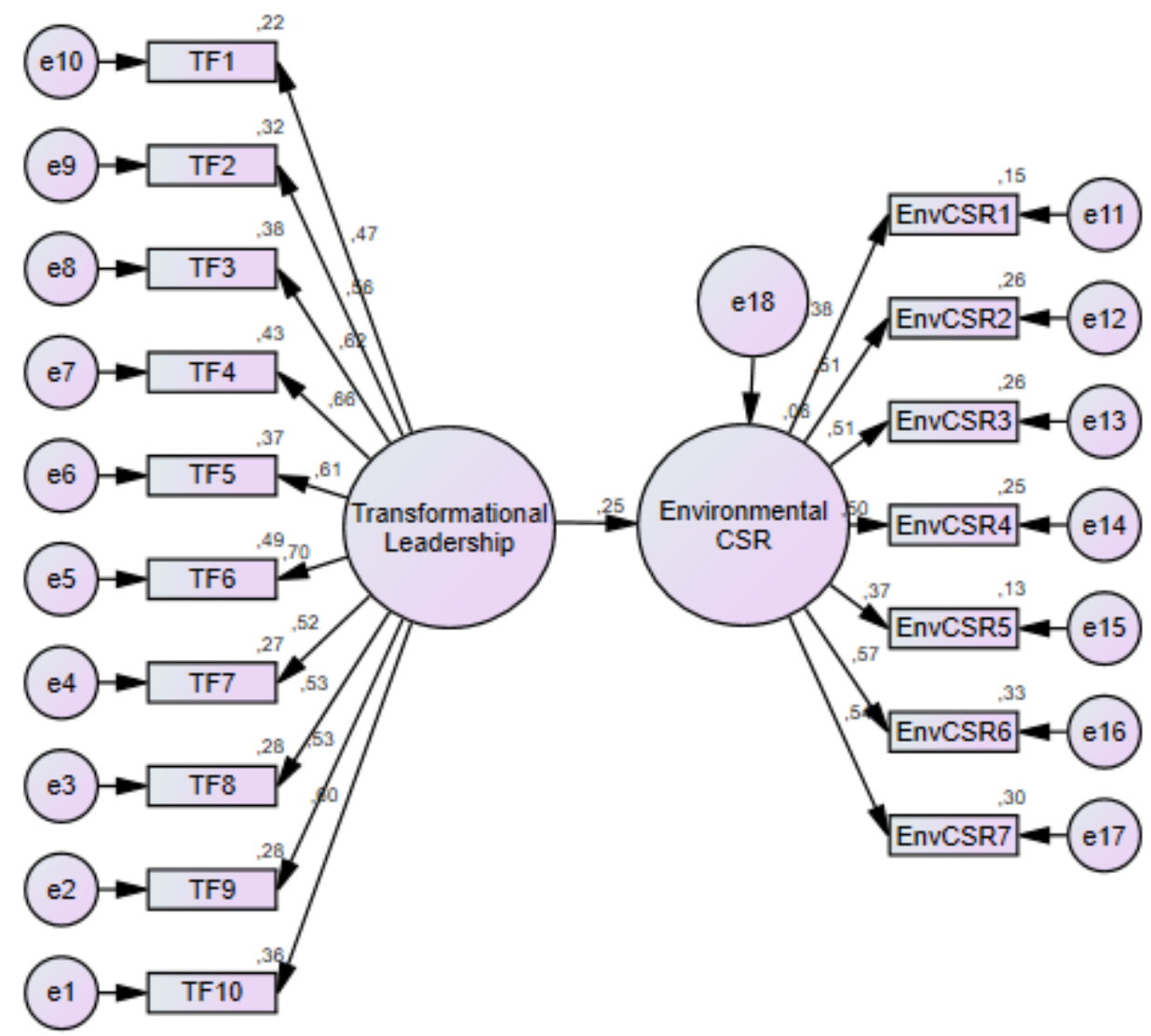

Figure 3. The effect of Transformational Leadership on Environmental CSR.

Table 4. Estimation of the Model 1 (Transformational Leadership on Environmental Corporate Social Responsibility (CSR)).

\begin{tabular}{ccccc}
\hline Construct & Coefficient & Std. Error & $\boldsymbol{t}$-Value & $\boldsymbol{p}$-Value \\
\hline $\begin{array}{c}\text { Transformational } \\
\text { Leadership }\end{array}$ & 0.255 & 0.097 & 3.190 & 0.001 \\
Moderator & 0.010 & 0.044 & 0.227 & 0.819 \\
\hline
\end{tabular}

The next measurement investigated the relationship between the independent variable of Transactional Leadership and the dependent variable of Environmental CSR, where the moderating variable of years of employment was unchanged. As a result, Transactional Leadership has a positive and statistically meaningful $(p<0.05)$ effect on Environmental CSR, where 1 unit of increase leads to a- 0.187 increase, respectively ( $\beta=0.187)$, which is an acceptable measure of the fit level. Employees' years of employment in their current companies did not have a significant moderating effect on the relationship between Transactional Leadership and Environmental CSR as well $(p>0.05)$. These measurements are shown in the following Figure 4 and Table 5. 


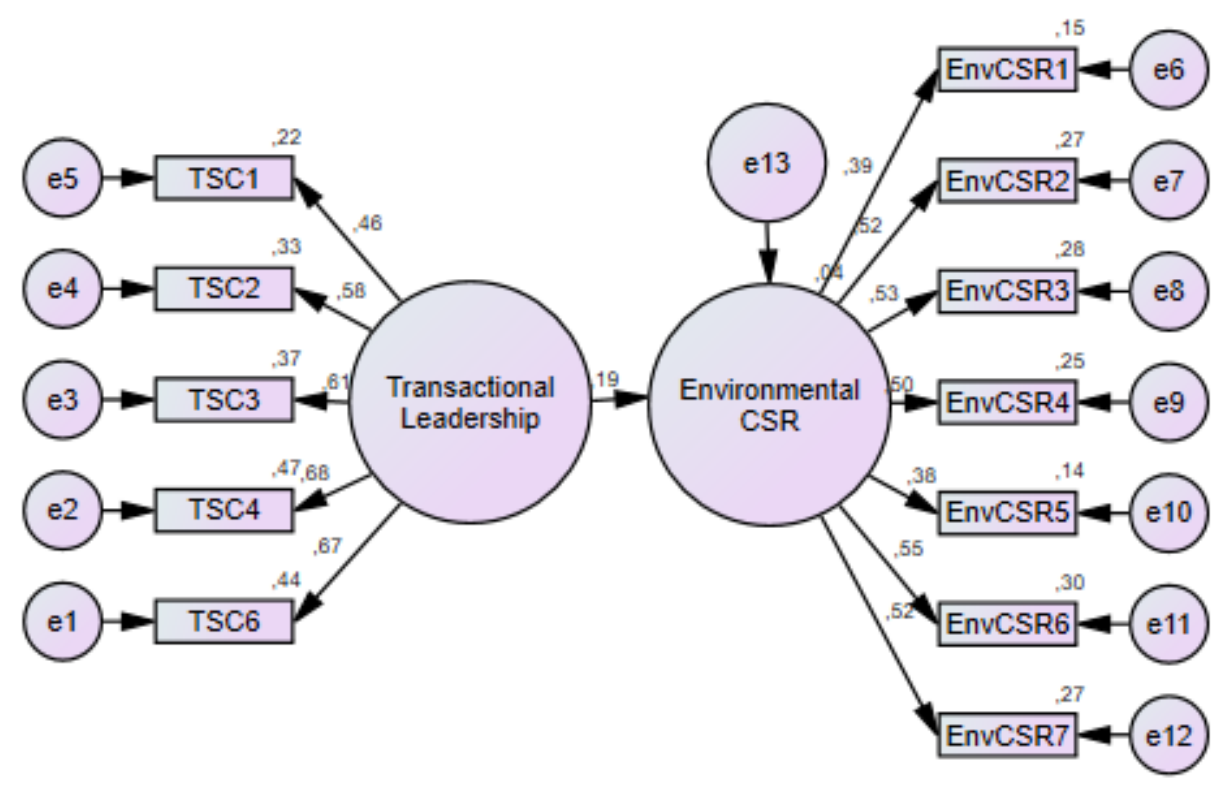

Figure 4. The effect of Transactional Leadership on Environmental CSR.

Table 5. Estimation of the Model 2 (Transactional Leadership on Environmental CSR).

\begin{tabular}{ccccc}
\hline Construct & Coefficient & Std. Error & $\boldsymbol{t}$-Value & $\boldsymbol{p}$-Value \\
\hline Transactional Leadership & 0.187 & 0.058 & 2.454 & 0.014 \\
Moderator & -0.011 & 0.040 & -0.286 & 0.774 \\
\hline
\end{tabular}

The next feature is on the relationship between the independent variable of Transformational Leadership and the dependent variable of Ethical CSR, where the moderator is stable. Calculations displayed a positive and statistically meaningful $(p<0.05)$ relationship between the variables, where 1 unit of increase in Transformational Leadership leads to a 0.688-unit increase in Ethical CSR $(\beta=0.688)$, which is a satisfactory degree. In addition, years of employment in current the company were measured to have a moderating effect on the relationship between Transformational Leadership and Ethical CSR $(p<0.05)$. The results are presented fully in the following Figure 5 and Table 6.

Table 6. Estimation of the Model 3 (Transformational Leadership on Ethical CSR).

\begin{tabular}{ccccc}
\hline Construct & Coefficient & Std. Error & $\boldsymbol{t}$-Value & $\boldsymbol{p}$-Value \\
\hline $\begin{array}{c}\text { Transformational } \\
\text { Leadership }\end{array}$ & 0.688 & 0.080 & 8.311 & 0.000 \\
\hline Moderator & 0.072 & 0.034 & 2.091 & 0.037 \\
\hline
\end{tabular}

After that, the relationship between the independent variable of Transactional Leadership and the dependent variable of Ethical CSR was investigated, with an unchanged moderating variable of years of employment. There was a noteworthy positive relationship $(p<0.05)$ between the variables, where 1 unit of increase in Transactional Leadership led to a 0.745 -unit increase in Ethical CSR $(\beta=0.745)$. On the other hand, the moderating variable was not established to have a moderating effect on the relationship between the variables $(p>0.05)$. The results are shown in the following Figure 6 and Table 7. 


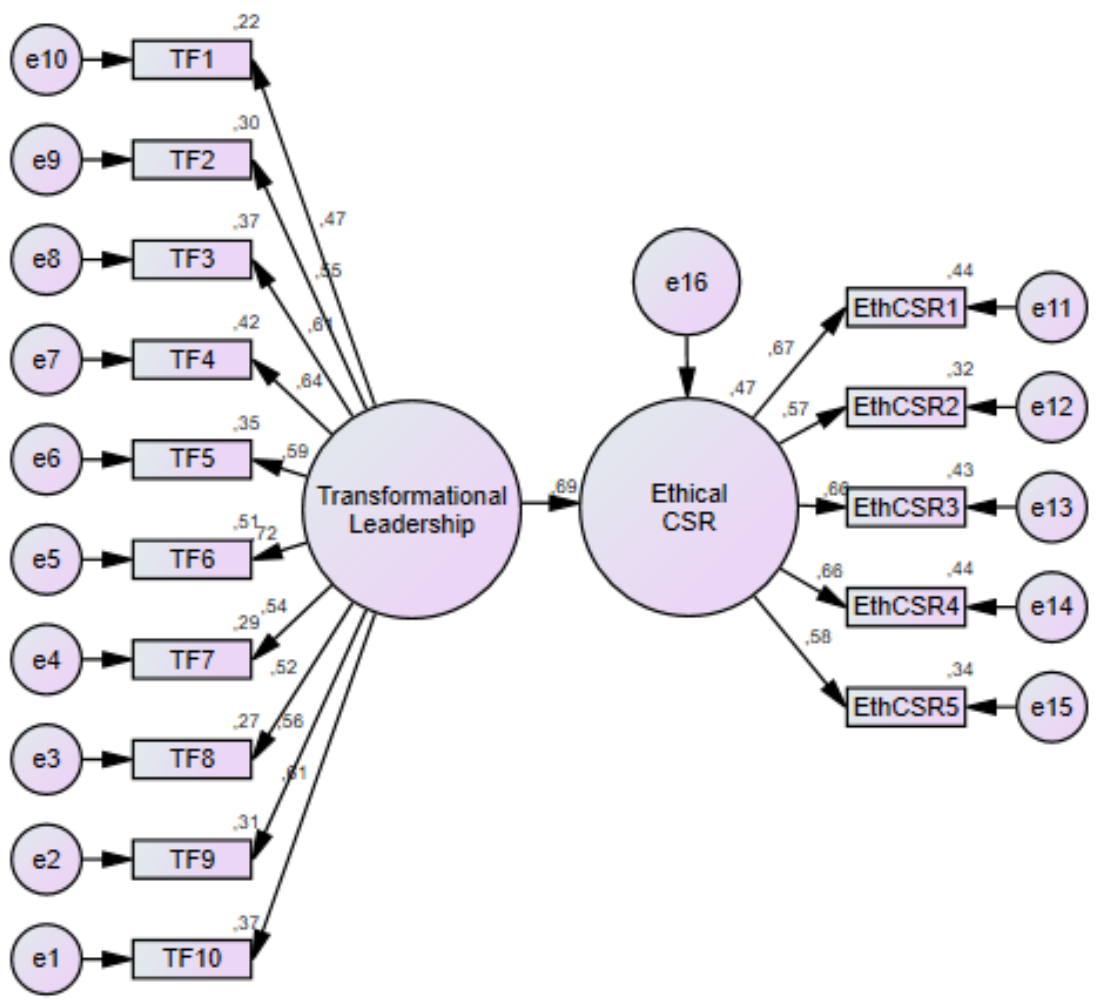

Figure 5. The effect of Transformational Leadership on Ethical CSR.

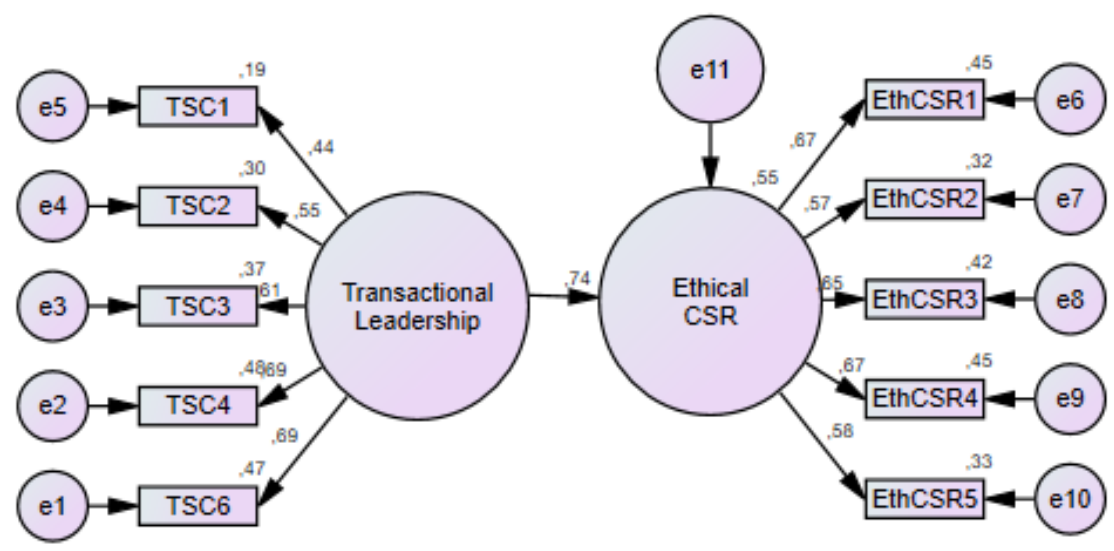

Figure 6. The effect of Transactional Leadership on Ethical CSR.

Table 7. Estimation of the Model 4 (Transactional Leadership on Ethical CSR).

\begin{tabular}{ccccc}
\hline Construct & Coefficient & Std. Error & $\boldsymbol{t}$-Value & $\boldsymbol{p}$-Value \\
\hline Transactional Leadership & 0.745 & 0.071 & 8.828 & 0.000 \\
\hline Moderator & 0.007 & 0.031 & 0.224 & 0.822 \\
\hline
\end{tabular}

\section{Discussion and Conclusions}

\subsection{Discussion}

Contemporary leadership approaches, in terms of their uniqueness and importance, have been increasingly studied by both academics and practitioners. Since there are various approaches to leadership, contemporary theories attempted to emphasize moral discourse and social purpose, which differs from the previous theories mainly focusing on favored 
management, authority, and production [109]. Prior research on specific contemporary theories of transformational and transactional leadership has generally been on the implementation of the theory and its relationship with job performance [110-112]. This study is deliberated as a significant contributor to the present literature since it provides a perspective on the effects of specific contemporary theories on particular aspects of Corporate Social Responsibility, in a scarce area of empirical research.

This study was conducted to research the effect of transformational and transactional leadership theories on environmental and ethical aspects of CSR, with the moderating variable of employees' years of employment in their current company. The theoretical model was tested through gathering data from employees working in the financial services sector, where the employees stated assessments regarding the actions of their leaders, their selves, and respective company. The data were used to test the relationship between the independent variables and dependent variables, as well as the moderating variable.

The results of the assessments displayed that a substantial connection is obvious with regard to implementing a transformational leadership approach to strengthen the impact of environmental and ethical CSR on organizational goals. Our findings correspond with the existing research on transformational leadership and environmental and ethical CSR [113,114]. For instance, the study of Graves et al. [115] enabled an opportunity for global comparison with China, where it was similarly established that a direct, positive link between transformational leadership and employees' environmentally responsible behavior is apparent. Similarly, transformational leadership was established to enhance environmental performance in the United Arab Emirates (UAE), based on a study conducted on SMEs operating in the manufacturing sector [116]. One way of deliberating our results is that the individualized consideration aspect of the transformational leadership approach enables leaders to communicate personally with every employee, leading employees to take more sensitive actions towards other stakeholders in return. Moreover, the inspirational motivation approach characteristic improves the determination of employees to fulfill organizational goals.

Furthermore, a noteworthy aspect of our findings was that the positive effect of transformational leadership was more than twice as high on ethical CSR (0.688) in comparison to environmental CSR (0.255). These findings conceivably refer to conceivable notions that the ethical aspect of our questionnaire's statements was presenting the organizational standpoint with examples such as "We are recognized as a trustworthy company", whereas the environmental aspect had personal statements such as "I print double sided whenever possible". Therefore, having organizational guidelines led employees to internalize ethical actions at an additional level than environmental ones.

Furthermore, the findings of our study presented that implementing the transactional leadership approach likewise had a positive effect on environmental and ethical CSR. These outcomes are parallel with our Hypotheses 1 and 2, as well as the part of the literature, agreeing with the influential aspect of transactional leadership on CSR activities [15,78,80]. On the other hand, it is in contrast with the studies stating there is no effect between the independent variable and dependent variables [117]. As an example, Ng and Burke [118], on the contrary to this study, did not establish a statistically meaningful link between transactional leadership and sustainable actions. However, this study was conducted on business students residing in the United States. Transactional leadership (0.187) had less influence on environmental CSR in comparison to transformational leadership (0.255). This might relate to the cross-culturally self-directed nature of the transformational leadership approach on subordinates' autonomous motivation [119], whereas transactional leadership operates certain reward and punishment systems. In addition, there was no reward or punishment on these explorations of environmental CSR statements, such as "I bring reusable utensils to work (e.g., coffee mug, reusable containers)". On the other hand, the effect on ethical CSR was more apparent (0.745) in comparison to transformational leadership (0.688). This can likewise be understood by the reward-punishment system, since breaking ethical CSR statements like "Fairness toward co-workers and business 
partners is an integral part of the employee evaluation processes" would produce undesired outcomes for employees. Nevertheless, this does not mean that transformational leaders would not punish undesirable behavior, but a clear punishment procedure might lead employees to take improved ethically responsible actions to some extent.

In addition, our findings on the hypotheses with regard to the moderating variable provided diverse results. Hypotheses 5, 7 and 8 were rejected, as employees' years of employment did not have a moderating effect on the relationship between transformational leadership and environmental CSR, as well as transactional leadership with environmental and ethical CSR. The moderating effect was positively visible only on the relationship between transformational leadership and ethical CSR. Although previous studies highlighted the importance of employee tenure on certain organizational objectives [96-98], our results suggested the contrary except for ethical actions of employees operating under transformational leaders. However, since all of the relationships between the independent variables and dependent variables are positively correlated, the lack of a moderating effect could be interpreted as employees already adopting certain behaviors during the initial time working with the leaders and retaining it at a steady level as years passed.

\section{Implications}

This investigation provides substantial contributions to theory and practice mutually, on leadership and corporate social responsibility aspects of organizations. The research empirically assesses the model on the influence of transformational and transactional leadership approaches, as well as the positive moderating impact of employees' years of employment in the current company, on environmental and ethical corporate social responsibility. The research indicated that organizations in the financial services sector can improve environmental and ethical aspects of corporate social responsibility through using both transformational and transactional leadership theories. This specifies that the offered model is an advancing approach in better comprehension of CSR. Such findings contribute to the research topic in the sense that transformational leadership was more influential on environmental CSR, where transactional leadership had a superior effect on the ethical aspect of CSR. Adopting these data as the starting point on leadership and CSR can also lead the researchers to examine which components of each leadership style lead to these changes between environmental and ethical CSR. Furthermore, the outcomes of this study contain additional managerial implications that can support leaders while setting socially responsible objectives for corporations. Transformational and transactional leadership approaches can be used complementarily to benefit from increased advantages. For instance, a leader who effectively combines the individualized consideration aspect of transformational leadership and contingent reward aspect of transactional leadership can convince the employees that multiple effects of actions should be considered simultaneously. The contingent reward aspect would present the employees a clear pathway into following guidelines to benefit the business, while the individualized consideration of each employee would assist in clarifying the vision behind such actions, as well as creating a sense of value. It is believed that the leadership approaches should be used interdependently to achieve such lasting outcomes.

In addition, our study can benefit shareholders in the sense of improving financial performance through CSR, since there are positive links between corporate social responsibility and awareness in relation to financial performance [120,121]. Precisely, Ali et al. [122] collected data from 229 companies in Pakistan suggesting that developing a positive image amongst stakeholders through CSR lowers overall costs, and improves financial performance. Thus, certain conflicting objectives with the shareholders can be viewed from this perspective by signifying that investment in CSR can lead to higher profit generation in the long term both directly and indirectly, through profits and brand image, respectively. Once the suitable approaches of leadership are implemented, stakeholders such as the society, customers, and employees can benefit from ethical and environmentally responsible actions, and shareholders can benefit from such enhanced financial gains. In this context, 
implementing the appropriate leadership styles is the key point of aiming to maintain the balance between implementing CSR practices and satisfying shareholder goals.

Accordingly, it is also worth noting that the previously mentioned concept of "green bonds" [26] is receiving increasing consideration from practitioners and scholars [123,124] The revenues of green bonds are used to fund an extensive range of activities such as sustainable change management and climate adaptation [125]. Thang and Zang [126] advocates that corporations' issuance of green bonds is beneficial to their existing shareholders. Therefore, the leaders of companies in the financial services industry can look towards green bonds as an effective way of implementing corporate social responsibility actions without compromising financial gains.

\subsection{Conclusions}

The importance of suitable leadership styles is recurrently highlighted, with the intention of creating desirable outcomes for stakeholders. Such intentions include environmentally and ethically responsible actions. The leadership styles chosen for this study were contemporary theories of transformational and transactional leadership, with the purpose of examining their impact on environmental and ethical CSR. The moderating effect of employees' years of employment in their respective companies was investigated as well. Our conclusions are that both of the independent variables had a statistically meaningful effect on dependent variables, and the moderating variable only had a positive effect on the relationship between transformational leadership and environmental CSR. In contrast, employees' years of employment did not have a moderating effect on the relationship between transactional leadership and dependent variables, as well as on the relationship between transformational leadership and ethical CSR.

As transformational and transactional leadership both had positive effects, but on different levels depending on environmental and ethical aspects of CSR, it can likewise be concluded that an effective combination of the two leadership styles can lead to improved results. The study also concludes that using appropriate leadership styles in companies operating in the financial services industry of the UK can improve the organizations' ethically and environmentally responsible actions towards stakeholders.

\subsection{Limitations and Further Research}

One limitation of this study is the singular focus on the financial services industry in the UK, meaning that the findings of the study are challenging to generalize in dissimilar business contexts. For that reason, replicating the study in different industries and countries can be attempted in future studies. As an example, replicating this study through focusing specifically on FinTech companies (e.g., crowdfunding, block chain) can potentially provide interesting outcomes for comparison. Moreover, although there has been extensive research on the research area, there is still room for further research. As leadership and corporate social responsibility are greatly comprehensive concepts, different approaches of leadership and CSR can be investigated with the aim of measuring additional correlations between the two concepts. Ketola [127] concluded that the approach of visionary leadership implemented interdependently with coherency creates desirable CSR outcomes. This approach can be tested by focusing specifically on the environmental aspect of CSR, which would be relevant while facing the climate change issues of the current pandemic era. As a final point, as opposed to the employees' perspective of the leaders and their selves, further research can measure the same topic from the leaders' perspective on their selves and employees.

Author Contributions: Supervision, T.A.; writing—original draft, M.C. All authors have read and agreed to the published version of the manuscript.

Funding: This research received no external funding. 
Institutional Review Board Statement: Ethical review and approval were waived for this study based on the consent of the thesis advisor, which is acknowledged by the ethical committee of the Cyprus International University.

Informed Consent Statement: Informed consent was obtained from all subjects involved in the study.

Data Availability Statement: The data backing the findings of this article will be made accessible by the authors, without undue reservation, to any qualified researcher.

Conflicts of Interest: The authors declare no conflict of interest.

\section{Appendix A}

Table A1. Items measurements and source.

\begin{tabular}{|c|c|c|}
\hline Construct & Items & Source \\
\hline \multirow{10}{*}{ Transformational Leadership } & My manager displays a sense of power and confidence & \multirow{10}{*}{ Bass and Avolio [99] } \\
\hline & My manager talks about their most important values and beliefs & \\
\hline & My manager spends time for teaching and coaching & \\
\hline & $\begin{array}{c}\text { My manager gets me to look at problems from } \\
\text { many different angles }\end{array}$ & \\
\hline & My manager articulates a compelling vision for the future & \\
\hline & My manager goes beyond self-interest for the good of the group & \\
\hline & $\begin{array}{l}\text { My manager treats me as an individual rather than just a } \\
\text { member of the group }\end{array}$ & \\
\hline & $\begin{array}{c}\text { My manager re-examines critical assumptions to question } \\
\text { whether they are appropriate }\end{array}$ & \\
\hline & My manager expresses confidence that goals will be achieved & \\
\hline & $\begin{array}{l}\text { My manager specifies the importance of having a strong } \\
\text { sense of purpose }\end{array}$ & \\
\hline \multirow{6}{*}{ Transactional Leadership } & $\begin{array}{c}\text { My manager discusses in specific terms who is responsible for } \\
\text { achieving performance target }\end{array}$ & \multirow{6}{*}{ Bass and Avolio [99] } \\
\hline & $\begin{array}{l}\text { My manager makes clear what one can expect to receive when } \\
\text { performance goals are achieved }\end{array}$ & \\
\hline & My manager expresses satisfaction when I meet expectations & \\
\hline & My manager is effective in meeting my job-related needs & \\
\hline & My manager gets me to do more than I expect to do & \\
\hline & My manager is effective in meeting organizational requirements & \\
\hline \multirow{7}{*}{ Environmental CSR } & I print double sided whenever possible & \multirow{7}{*}{ Robertson and Barling [17] } \\
\hline & I put compostable items in the compost bin & \\
\hline & $\begin{array}{l}\text { I put recyclable material (e.g., cans, paper, bottles) in } \\
\text { the recycling bins }\end{array}$ & \\
\hline & $\begin{array}{l}\text { I bring reusable utensils to work (e.g., coffee } \\
\text { mug, reusable containers) }\end{array}$ & \\
\hline & I turn lights off when not in use & \\
\hline & $\begin{array}{l}\text { I take part in environmentally friendly programs (e.g., } \\
\text { bike/walk to work day) }\end{array}$ & \\
\hline & $\begin{array}{l}\text { I make suggestions about environmentally friendly practices to } \\
\text { managers and/or environmental committees, in an effort to } \\
\text { increase my organization's environmental performance. }\end{array}$ & \\
\hline \multirow{5}{*}{ Ethical CSR } & Our business has a comprehensive code of conduct & \multirow{5}{*}{ Maignan and Ferrell [100] } \\
\hline & We are recognized as a trustworthy company & \\
\hline & $\begin{array}{l}\text { Fairness toward co-workers and business partners is an integral } \\
\text { part of the employee evaluation process }\end{array}$ & \\
\hline & $\begin{array}{l}\text { A confidential procedure is in place for employees to report any } \\
\text { misconduct at work }\end{array}$ & \\
\hline & $\begin{array}{l}\text { Our salespersons and employees are required to provide full and } \\
\text { accurate information to all customers }\end{array}$ & \\
\hline
\end{tabular}




\section{References}

1. Babiak, K.; Trendafilova, S. CSR and environmental responsibility: Motives and pressures to adopt green management practices. Corp. Soc. Responsib. Environ. Manag. 2011, 18, 11-24. [CrossRef]

2. Lee, E.M.; Park, S.Y.; Lee, H.J. Employee perception of CSR activities: Its antecedents and consequences. J. Bus. Res. 2013, 66, 1716-1724. [CrossRef]

3. Matten, D.; Moon, J. Implicit and explicit CSR: A conceptual framework for a comparative understanding of corporate social responsibility. Acad. Manag. Rev. 2008, 33, 404-424. [CrossRef]

4. Siddiq, S.; Javed, S. Impact of CSR on organizational performance. Eur. J. Bus. Manag. 2014, 6, 40-45.

5. Gibson, R. Rethinking the leadership agenda: While business has moved to a new level of complexity, many leaders remain stuck in the past. With leadership more crucial than ever, a radically different set of competencies is required. Financ. Exec. 2003, 19, 30-35.

6. Jones, M.T.; Millar, C.C. About global leadership and global ethics, and a possible moral compass: An introduction to the special issue. J. Bus. Ethics 2010, 93, 1-8. [CrossRef]

7. Waldman, D.A.; Siegel, D.S.; Javidan, M. Components of CEO transformational leadership and corporate social responsibility. J. Manag. Stud. 2006, 43, 17031725. [CrossRef]

8. Jones Christensen, L.I.S.A.; Mackey, A.; Whetten, D. Taking responsibility for corporate social responsibility: The role of leaders in creating, implementing, sustaining, or avoiding socially responsible firm behaviors. Acad. Manag. Perspect. 2014, 28, 164-178.

9. Avolio, B.J. Full Leadership Development: Building the Vital Forces in Organizations; Sage: London, UK, 1999.

10. Ming, W.W.P.; Tee, N.E.; Hua, C.C. Transformational leadership, motivation, and organizational commitment towards corporate social responsibility in banking service industry, sarawak. Glob. Bus. Manag. Res. 2018, 10, 58-70.

11. Strand, R. Exploring the role of leadership in corporate social responsibility: A review. J. Leadersh. Account. Ethics 2011, 8, 84-96.

12. Angus-Leppan, T.; Metcalf, L.; Benn, S. Leadership styles and CSR practice: An examination of sensemaking, institutional drivers and CSR leadership. J. Bus. Ethics 2010, 93, 189-213. [CrossRef]

13. Groves, K.S.; LaRocca, M.A. Responsible leadership outcomes via stakeholder CSR values: Testing a values-centered model of transformational leadership. In Responsible Leadership; Springer: Dordrecht, The Netherlands, 2011; pp. 37-55.

14. Ali, S.H.; Yildiz, Y. Leadership effects on CSR employee, media, customer, and NGOs. Manag. Econ. Res. J. 2020, 6, 12354. [CrossRef]

15. Ho, J.A.; Ang, Y.H.; Tee, K.K. Institutional corporate social responsibility (CSR) practices: The influence of leadership styles and their perceived ethics and social responsibility role. Pertanika J. Soc. Sci. Humanit. 2015, 23, 17-32.

16. Manzoor, F.; Wei, L.; Nurunnabi, M.; Subhan, Q.A.; Shah, S.I.A.; Fallatah, S. The impact of transformational leadership on job performance and CSR as mediator in SMEs. Sustainability 2019, 11, 436. [CrossRef]

17. Robertson, J.L.; Barling, J. Greening organizations through leaders' influence on employees' pro-environmental behaviors. J. Organ. Behav. 2013, 34, 176-194. [CrossRef]

18. Vecchio, R.P. Leader-member exchange, objective performance, employment duration, and supervisor ratings: Testing for moderation and mediation. J. Bus. Psychol. 1998, 12, 327-341.

19. Budur, T.; Demir, A. Leadership effects on employee perception about CSR in Kurdistan Region of Iraq. Int. J. Soc. Sci. Educ. Stud. 2019, 5, 184.

20. Du, S.; Swaen, V.; Lindgreen, A.; Sen, S. The roles of leadership styles in corporate social responsibility. J. Bus. Ethics 2013, 114, 155-169. [CrossRef]

21. The World Bank. GDP Growth-United Kingdom. 2020. Available online: https://data.worldbank.org/indicator/NY.GDP. MKTP.KD.ZG?end=2019\&locations=GB\&start=2015 (accessed on 26 August 2020).

22. UK Parliament. Financial services: Contribution to the UK Economy. 2019. Available online: https://commonslibrary.parliament. uk/research-briefings/sn06193/ (accessed on 26 August 2020).

23. The City UK. Key Facts about the UK as an International Financial Centre. 2018. Available online: https://cdn.ymaws.com/ www.export.org.uk/resource/resmgr/media/news/key-facts-about-the-uk-as-an.pdf (accessed on 26 August 2020).

24. New York Times. Royal Bank of Scotland Plans to Cut 3500 Jobs. 2010. Available online: https://www.nytimes.com/2010/09/03 /business/global/03rbs.html (accessed on 27 August 2020).

25. Day, R.; Woodward, T. CSR reporting and the UK financial services sector. J. Appl. Account. Res. 2009, 10, 159-175. [CrossRef]

26. The City UK and Imperial College Business School. Understanding Green Bonds. 2018. Available online: https://www.thecityuk. com/assets/2018/Reports-PDF/bf2095d362/Understanding-Green-Bonds.pdf (accessed on 27 August 2020).

27. Ogbonna, E.; Harris, L.C. Leadership style, organizational culture and performance: Empirical evidence from UK companies. Int. J. Hum. Resour. Manag. 2000, 11, 766-788. [CrossRef]

28. Khattak, S.I.; Jiang, Q.; Li, H.; Zhang, X. Corporate social responsibility (CSR) and leadership: Validation of a multi-factor framework in the United Kingdom (UK). J. Bus. Econ. Manag. 2019, 20, 754-776. [CrossRef]

29. Frederick, W.C. Corporation, Be Good! The Story of Corporate Social Responsibility; Dog Ear Publishing: Indianapolis, IN, USA, 2006.

30. Bendell, J. In whose name? The accountability of corporate social responsibility. Dev. Pract. 2005, 15, 362-374.

31. Bowen, H.R. Social Responsibilities of the Businessman; Harper: New York, NY, USA, 1953.

32. Kashyap, R.; Mir, R.; Mir, A. Corporate social responsibility: A call for multidisciplinary inquiry. J. Bus. Econ. Res. 2004, 2. [CrossRef] 
33. Agudelo, M.A.L.; Jóhannsdóttir, L.; Davídsdóttir, B. A literature review of the history and evolution of corporate social responsibility. Int. J. Corp. Soc. Responsib. 2019, 4, 1.

34. Jones, T.M. Corporate social responsibility revisited, redefined. Calif. Manag. Rev. 1980, 22, 59-67. [CrossRef]

35. Smith, N.C. Changes in corporate practices in response to public interest advocacy and actions. Handb. Mark. Soc. 2001, 140-161. [CrossRef]

36. Harjoto, M.A.; Jo, H. Corporate governance and CSR nexus. J. Bus. Ethics 2011, 100, 45-67. [CrossRef]

37. He, H.; Harris, L. The impact of Covid-19 pandemic on corporate social responsibility and marketing philosophy. J. Bus. Res. 2020, 116, 176-182. [CrossRef]

38. Wolff, S.; Ladi, S. European Union Responses to the Covid-19 Pandemic: Adaptability in times of Permanent Emergency. J. Eur. Integr. 2020, 42, 1025-1040. [CrossRef]

39. Williamson, D.; Lynch-Wood, G.; Ramsay, J. Drivers of environmental behaviour in manufacturing SMEs and the implications for CSR. J. Bus. Ethics 2006, 67, 317-330. [CrossRef]

40. Flammer, C. Corporate social responsibility and shareholder reaction: The environmental awareness of investors. Acad. Manag. J. 2013, 56, 758-781. [CrossRef]

41. Porter, M.E.; Van der Linde, C. Toward a new conception of the environment competitiveness relationship. J. Econ. Perspect. 1995, 9, 97-118. [CrossRef]

42. Cox, M.J. Sustainable communication: A study of green advertising and audience reception within the growing arena of corporate social responsibility. Case study: British Petroleum. Earth Environ. 2008, 3, 32-51.

43. Abdul, Z.; Ibrahim, S. Executive and management attitudes towards corporate social responsibility in Malaysia. Corp. Gov. Int. J. Bus. Soc. 2002, 2, 10-16. [CrossRef]

44. Agle, B.R.; Mitchell, R.K.; Sonnenfeld, J.A. Who matters to Ceos? An investigation of stakeholder attributes and salience, corpate performance, and Ceo values. Acad. Manag. J. 1999, 42, 507-525.

45. Galton, F. Hereditary Genius: An Inquiry into Its Laws and Consequences; Macmillan: New York, NY, USA, 1869 ; Volume 27.

46. Batten, J.D. Tough-Minded Leadership; Wipf and Stock Publishers: Eugene, OR, USA, 2001.

47. Northouse, P.G. Leadership: Theory and Practice; SAGE Publications: London, UK, 2010.

48. Ciulla, J.B. The Ethics of Leadership; Wadsworth/Thomson Learning: San Francisco, CA, USA, 2003.

49. Hofstede, G. Culture's Consequences: Comparing Values, Behaviors, Institutions and Organizations Across Nations; Sage Publications: London, UK, 2001.

50. Bennis, W.; Nanus, B. The Strategies for Taking Charge; Leaders: New York, NY, USA, 1985.

51. Colbert, A.E.; Judge, T.A.; Choi, D.; Wang, G. Assessing the trait theory of leadership using self and observer ratings of personality: The mediating role of contributions to group success. Leadersh. Q. 2012, 23, 670-685. [CrossRef]

52. Zopiatis, A.; Constanti, P. Extraversion, openness and conscientiousness. Leadersh. Organ. Dev. J. 2012, 33, 86-104. [CrossRef]

53. Judge, T.A.; Bono, J.E.; Ilies, R.; Gerhardt, M.W. Personality and leadership: A qualitative and quantitative review. J. Appl. Psychol. 2002, 87, 765. [CrossRef]

54. Myung, J.K.; Choi, Y.H. The influences of leaders' dark triad trait on their perception of CSR. Asian J. Sustain. Soc. Responsib. 2017, 2, 7-21. [CrossRef]

55. Shooshtarian, Z.; Amini, M. The study of relationship between leaders' behavior and efficiency and return on investment. Pol. J. Manag. Stud. 2012, 6, 55-67.

56. Blake, R.R.; Mouton, J.S.; Bidwell, A.C. Managerial grid. In Advanced Management-Office Executive; Gulf Publishing Company: Houston, TX, USA, 1962.

57. McGregor, D. Theory X and theory Y. Organ. Theory 1960, 358, 374.

58. Fiedler, F.E. A contingency model of leadership effectiveness. In Advances in Experimental Social Psychology; Academic Press: Cambridge, MA, USA, 1964; Volume 1, pp. 149-190.

59. House, R.J.; Mitchell, T.R. Path-Goal Theory of Leadership; No. TR-75-67; Washington University Seattle Department of Psychology: Seattle, WA, USA, 1975.

60. Gill, R. Theory and Practice of Leadership; SAGE Publications: London, UK, 2011.

61. House, R.J.A. Theory of Charismatic Leadership; Working Paper Series 76-06; Toronto University: Toronto, ON, Canada, 1976; 38p.

62. Graham, J.W. Servant-leadership in organizations: Inspirational and moral. Leadersh. Q. 1991, 2, 105-119. [CrossRef]

63. Burns, J.M. Transformational Leadership Theory; Leadership: New York, NY, USA, 1978.

64. Bass, B.M. Leadership and Performance beyond Expectations; Simon \& Schuster: New York, NY, USA, 1985.

65. Robbins, S.P.; Judge, T. Organizational Behavior (Global Edition); Pearson Education: Essex, UK, 2014.

66. Bass, B.M.; Avolio, B.J.; Atwater, L. The transformational and transactional leadership of men and women. Appl. Psychol. 1996, 45, 5-34. [CrossRef]

67. Avolio, B.J.; Bass, B.M. Manual for the Multifactor Leadership Questionnaire (Form 5X); Mindgarden: Redwood City, CA, USA, 2002.

68. House, R.J.; Shamir, B. Toward the Integration of Transformational, Charismatic, and Visionary Theories; Academic Press: Cambridge, MA, USA, 1993.

69. Yukl, G. An Evaluation of the Conceptual Weaknesses in Transformational and Charismatic Leadership Theories. Leadersh. Q. 1999, 10, 285-305. [CrossRef] 
70. Ng, L.T.; Rivera, J.R. Exploring transformational leadership and fellowship in a cultural context: The case of the Philippines. Asia-Pac. Soc. Sci. Rev. 2018, 17, 136-141.

71. Bass, B.M. Transformational Leadership: Industrial, Military, and Educational Impact; Erlbaum: Mahwah, NJ, USA, 1998.

72. Walumbwa, F.O.; Avolio, B.J.; Gardner, W.L.; Wernsing, T.S.; Peterson, S.J. Authentic leadership: Development and validation of a theory-based measure. J. Manag. 2008, 34, 89-126. [CrossRef]

73. Jones, T.M. Instrumental stakeholder theory: A synthesis of ethics and economics. Acad. Manag. Rev. 1995, 20, 404-437. [CrossRef]

74. Chen, Y.R.R.; Hung-Baesecke, C.J.F. Examining the Internal Aspect of Corporate Social Responsibility (CSR): Leader Behavior and Employee CSR participation. Commun. Res. Rep. 2014, 31, 210-220. [CrossRef]

75. Pasricha, P.; Singh, B.; Verma, P. Ethical leadership, organic organizational cultures and corporate social responsibility: An empirical study in social enterprises. J. Bus. Ethics 2018, 151, 941-958. [CrossRef]

76. Juneja, P. Transactional Leadership Theory. Management Study Guide. 2019. Available online: https://managementstudyguide. com/transformational-leadership.htm (accessed on 5 October 2020).

77. Jacobs, C.; Pfaff, H.; Lehner, B.; Driller, E.; Nitzsche, A.; Stieler-Lorenz, B.; Jung, J. The influence of transformational leadership on employee well-being: Results from a survey of companies in the information and communication technology sector in Germany. J. Occup. Environ. Med. 2013, 55, 772-778. [CrossRef]

78. Kanungo, R.N. Ethical values of transactional and transformational leaders. Can. J. Adm. Sci. 2001, 18, 257-265. [CrossRef]

79. Hazlett, S.A.; McAdam, R.; Sohal, A.; Shahin, A.; Zairi, M. Corporate governance as a critical element for driving excellence in corporate social responsibility. Int. J. Qual. Reliab. Manag. 2007, 24, 753-770.

80. Egri, C.P.; Herman, S. Leadership in the North American environmental sector: Values, leadership styles, and contexts of environmental leaders and their organizations. Acad. Manag. J. 2000, 43, 571-604.

81. Tuan, L.T. Corporate social responsibility, leadership, and brand equity in healthcare service. Soc. Responsib. J. 2012, 8, 347-362. [CrossRef]

82. Székely, F.; Knirsch, M. Responsible leadership and corporate social responsibility: Metrics for sustainable performance. Eur. Manag. J. 2005, 23, 628-647. [CrossRef]

83. Spreitzer, G.; Perttula, K.H.; Xin, K. Traditionality Matters: An Examination of the Effectiveness of Transformational Leadership in the US and Taiwan. J. Organ. Behav. 2005, 26, 205-227. [CrossRef]

84. Bass, B.M.; Avolio, B.J. Transformational leadership and organizational culture. Public Adm. Q. 1993, 17, 112-121. [CrossRef]

85. Waldman, D.A.; Ramirez, G.G.; House, R.J.; Puranam, P. Does leadership matter? CEO leadership attributes and profitability under conditions of perceived environmental uncertainty. Acad. Manag. J. 2001, 44, 134-143.

86. Pillai, R.; Williams, E.A. Transformational leadership, self-efficacy, group cohesiveness, commitment, and performance. J. Organ. Chang. Manag. 2004, 17, 144-159.

87. Turner, N.; Barling, J.; Epitropaki, O.; Butcher, V.; Milner, C. Transformational leadership and moral reasoning. J. Appl. Psychol. 2002, 87, 304.

88. Wabitsch, V.V. How to Motivate Managers for CSR? Commitment to CSR by Transformational Leadership in Meetings. Ph.D. Thesis, University of Lisbon, Lisbon, Portugal, 2014.

89. Hadi, N.U.; Rasool, F. Environmental Transformational Leadership and Employee Pro-Envirnmental Behaviours: The Bridging Role of Autonomous Motivation. Abasyn J. Soc. Sci. 2017, 10, 42-53.

90. Allen, G.W.; Attoh, P.A.; Gong, T. Transformational leadership and affective organizational commitment: Mediating roles of perceived social responsibility and organizational identification. Soc. Responsib. J. 2017. [CrossRef]

91. Cannella, A.A., Jr.; Park, J.H.; Lee, H.U. Top management team functional background diversity and firm performance: Examining the roles of team member colocation and environmental uncertainty. Acad. Manag. J. 2008, 51, 768-784.

92. Alonso-Almeida, M.D.M.; Perramon, J.; Bagur-Femenias, L. Leadership styles and corporate social responsibility management: Analysis from a gender perspective. Bus. Ethics Eur. Rev. 2017, 26, 147-161. [CrossRef]

93. Chatman, J.A. Matching people and organizations: Selection and socialization in public accounting firms. In Academy of Management Proceedings; Academy of Management: Briarcliff Manor, NY, USA, 1989; Volume 1989, pp. $199-203$.

94. Huang, S.K. The impact of CEO characteristics on corporate sustainable development. Corp. Soc. Responsib. Environ. Manag. 2013, 20, 234-244.

95. Steffens, N.K.; Shemla, M.; Wegge, J.; Diestel, S. Organizational tenure and employee performance: A multilevel analysis. Group Organ. Manag. 2014, 39, 664-690. [CrossRef]

96. Wiersema, M.F.; Bird, A. Organizational demography in Japanese firms: Group heterogeneity, individual dissimilarity, and top management team turnover. Acad. Manag. J. 2017, 36, 5.

97. Wright, T.A.; Bonett, D.G. The moderating effects of employee tenure on the relation between organizational commitment and job performance: A meta-analysis. J. Appl. Psychol. 2002, 87, 1183. [CrossRef]

98. Kim, T.Y.; Liu, Z.; Diefendorff, J.M. Leader-member exchange and job performance: The effects of taking charge and organizational tenure. J. Organ. Behav. 2015, 36, 216-231. [CrossRef]

99. Bass, B.M.; Avolio, B.J. Multifactor Leadership Questionnaire: Leader Form, Rater Form, and Scoring Key for MLQ (Form 5x-Short); Mind Garden: Redwood City, CA, USA, 1995.

100. Maignan, I.; Ferrell, O.C. Measuring corporate citizenship in two countries: The case of the United States and France. J. Bus. Ethics 2000, 23, 283-297. [CrossRef] 
101. Barling, J.; Loughlin, C.; Kelloway, E.K. Development and test of a model linking safety-specific transformational leadership and occupational safety. J. Appl. Psychol. 2002, 87, 488. [CrossRef] [PubMed]

102. Jung, D.I.; Avolio, B.J. Opening the black box: An experimental investigation of the mediating effects of trust and value congruence on transformational and transactional leadership. J. Organ. Behav. 2000, 21, 949-964. [CrossRef]

103. Aurigin. Companies Directory List. 2020. Available online: https://www.aurigininc.com/c/United-Kingdom/FinancialServices-Companies/GB/8/All/1 (accessed on 18 June 2020).

104. Hox, J.J.; Bechger, T.M. An Introduction to Structural Equation Modelling. Fam. Sci. Rev. 1998, 11, 354-373.

105. Kline, R.B. Principles and Practice of Structural Equation Modeling; Guilford Publications: New York, NY, USA, 2015.

106. Chan, Y.H. Biostatistics 101: Data presentation. Singap. Med. J. 2003, 44, 280-285.

107. Terzi, Y. SPSS 20.0. 2014. Available online: https:// www.academia.edu/20308561/SPSS20_2014 (accessed on 25 September 2020).

108. Churchill, G.A.; Suprenant, C. A paradigm for developing better measures for marketing of consumer satisfaction. J. Mark. 1979, $16,491-504$.

109. Komives, S.R.; Dugan, J.P. Contemporary leadership theories. Political Civ. Leadersh. Ref. Handb. 2010, 1, 111-120.

110. Ng, T.W. Transformational leadership and performance outcomes: Analyses of multiple mediation pathways. Leadersh. Q. 2017, 28, 385-417. [CrossRef]

111. Walumbwa, F.O.; Hartnell, C.A. Understanding transformational leadership-employee performance links: The role of relational identification and self-efficacy. J. Occup. Organ. Psychol. 2011, 84, 153-172. [CrossRef]

112. Bacha, E. The relationship between transformational leadership, task performance and job characteristics. J. Manag. Dev. 2014. [CrossRef]

113. Bass, B.M.; Steidlmeier, P. Ethics, character and authentic transformational leadership behavior. Leadersh. Q. 1999, 10, 181-217. [CrossRef]

114. Pless, N.M.; Maak, T. Responsible leadership: Pathways to the future. J. Bus. Ethics 2011, 98, 3-13. [CrossRef]

115. Graves, L.M.; Sarkis, J.; Zhu, Q. How transformational leadership and employee motivation combine to predict employee proenvironmental behaviors in China. J. Environ. Psychol. 2013, 35, 81-91. [CrossRef]

116. Singh, S.K.; Del Giudice, M.; Chierici, R.; Graziano, D. Green innovation and environmental performance: The role of green transformational leadership and green human resource management. Technol. Forecast. Soc. Chang. 2020, 150, 119762. [CrossRef]

117. Nazir, A.; Arshad, M.; Shakaib, M. How does managers' leadership styles influence institutional CSR activities? Employees perspective. J. Basic Appl. Sci. Res. 2014, 4, 175-180.

118. Ng, E.S.; Burke, R.J. Predictor of business students' attitudes toward sustainable business practices. J. Bus. Ethics 2010, 95, 603-615. [CrossRef]

119. Wang, Z.; Gagné, M. A Chinese-Canadian cross-cultural investigation of transformational leadership, autonomous motivation, and collectivistic value. J. Leadersh. Organ. Stud. 2013, 20, 134-142. [CrossRef]

120. Rhou, Y.; Singal, M.; Koh, Y. CSR and financial performance: The role of CSR awareness in the restaurant industry. Int. J. Hosp. Manag. 2016, 57, 30-39. [CrossRef]

121. Fauzi, H.; Idris, K. The relationship of CSR and financial performance: New evidence from Indonesian companies. Issues Soc. Environ. Account. 2009, 3. [CrossRef]

122. Ali, H.Y.; Danish, R.Q.; Asrarul-Haq, M. How corporate social responsibility boosts firm financial performance: The mediating role of corporate image and customer satisfaction. Corp. Soc. Responsib. Environ. Manag. 2020, 27, 166-177. [CrossRef]

123. Flammer, C. Corporate Green Bonds. J. Financ. Econ. 2020. [CrossRef]

124. Baker, M.; Bergstresser, D.; Serafeim, G.; Wurgler, J. Financing the Response to Climate Change: The Pricing and Ownership of US Green Bonds; No. w25194; National Bureau of Economic Research: Cambridge, MA, USA, 2018. [CrossRef]

125. Bloomberg. Investors Are Willing to Pay a "Green" Premium-Bloomberg New Energy Finance Report; BloombergNEF: London, UK, 2017.

126. Tang, D.Y.; Zhang, Y. Do shareholders benefit from green bonds? J. Corp. Financ. 2020, 61, 101427. [CrossRef]

127. Ketola, T. Do you trust your boss? A Jungian analysis of leadership reliability in CSR. Electron. J. Bus. Ethics Organ. Stud. 2006, 11, 6-14. 